\title{
Evaluation of IPM modules for the management of fruit borer and fruit rot diseases in tomato, Lycopersicon esculentum Miller
}

\author{
S. D. Sharma, R. Devlash *, Jitender Kumar, Brij Bala, R. S. Jamwal
}

Chaudhary Sarwan Kumar Himachal Pradesh Krishi Vishvavidyalaya, Hill Agricultural Research and Extension Centre, Bajaura. Distt. Kullu-175125 (Himanchal Pardesh), INDIA

${ }^{*}$ Corresponding author. E-mail: devlashbajaura@rediffmail.com

Received: June 6, 2015; Revised received: September 21, 2015; Accepted: February 20, 2016

\begin{abstract}
Among, five IPM modules tested against tomato fruit borer and fruit rot on tomato, the IPM module $\left(\mathrm{M}_{3}\right)$ consisting of use of pheromone traps (@ 12 traps/ha) just after transplanting the tomato crop , Lycopersicon esculentum Miller for monitoring the population of Helicoverpa armigera. followed by three foliar sprays commencing with a mixture of lamba-cyhalothrin 5EC @ 0.8ml/L(0.04\%) and Dithane Z-78 (Zineb) @ 2.5g/L (0.25\%) after 10 days of appearance of moths in the traps (after 30 days of transplanting) followed by spray with a mixture of Helicide (Ha NPV) 100 LE @ 0.5ml/L+ Indofil M-45 @ 2.5g/L (0.25\%) + Gur (0.05\%) + Tween $80(0.05 \%)$ after 15 days of first spray followed by spray with a mixture of lamba-cyhalothrin 5 EC @ $0.8 \mathrm{ml} / \mathrm{L}(0.04 \%)$ and moximate (cymoxanil + mancozeb) @ $0.25 \%$ after 15 days of the second spray was found to be most effective in minimizing the infestation of fruit borer and fruit rot diseases with $50.00 \%$ and $63.45 \%$ reduction over control, respectively. This module was also found to be most economic resulting in highest marketable fruit yield $(255.94 \mathrm{q} / \mathrm{ha})$ and maximum net returns (Rs.10.36) per rupee spent. The present findings are of immense utility as there will be reduction in number of sprays resulting in the cost of production of tomato crop.
\end{abstract}

Keywords: Foliar sprays, Fruit borer, Fruit rot diseases, IPM module, Tomato

\section{INTRODUCTION}

Tomato Lycopersicon esculentum Miller is an important vegetable crop grown all over the world. Insect pests and diseases are the most important biological limitations in tomato production. Among the various insect pests, infesting this crop tomato fruit borer, Helicoverpa armigera (Hubner) has been a major constraint causing extensive damage to the fruits of tomato to the extent of about 50-70 per cent (Reddy and Tangtrakulwanish, 2013; Abbas et al., 2015). Tomato growers are also confronted with the great loss from diseases caused by fungi and bacteria. Out of these, fungal diseases are the most common which cause considerable loss to tomato fruits . Among fungal diseases Alternaria rot caused by, Alternaria solani, buckeye rot caused by Phytophthora parasitica, Phytophthora rot caused by Phytophthora infestans are the serious ones causing yield losses from $12.67 \%$ to $91.80 \%$ (Wani, 2011; Chaurasia, et al., 2013). Due to these diseases, the fruits not only lose their nutritive value, but also there is quick and severe rotting making them unfit for human consumption.

Several researchers have reported the control of tomato fruit borer and fruit rot diseases by the spray of insecticides and fungicides separately. But for the efficient use of time, labour and resources, the present investigation were carried out with an objective to evaluate the efficacy of five IPM modules consisting of mix- tures of insecticides and fungicides taking in to account their compatibility for the ecofriendly and economical management of tomato fruit borer and fruit rot diseases.The present studies using combination of insecticides and fungicides hold an immense promise from farmers view point and will go a long way in the reduction of number of sprays to half along with the reduction in the cost of production and inconvenience caused to them.

\section{MATERIALS AND METHODS}

Field trials were conducted during kharif 2011 and 2012 at 3 sites at and around Hill Agricultural Research and Extension Centre, Bajaura, Distt. Kullu (Himachal Pradesh). The experiments were laid out in randomized block design with 5 treatments, each replicated 4 times. About 1 month old seedlings of tomato (cv. Hybrid RK-123) were transplanted during kharif 2011 and 2012 at a spacing of $60 \mathrm{~cm} \mathrm{x} 45 \mathrm{~cm}$ in plots of $3.00 \times 2.70 \mathrm{~m}$. Nursery beds were treated with formaldehyde@1:7 and covered with polythene sheet for 7 days for proper fumigation. Sowing was done after 7 days of removal of polythene sheet in nursery bed after intermittent pulverizing the soil and when there was no smell of formalin. The seedlings were dipped before transplanting in a solution of carbendazim @ $1.0 \mathrm{~g}$ per litre of water for 30 minutes.All the cultural practices were adopted as per the recommendation of Package of Practices of Vegetable crops of Chaudhary Sarwan ISSN : 0974-9411 (Print), 2231-5209 (Online) All Rights Reserved (C Applied and Natural Science Foundation www.ansfoundation.org 
Kumar Himachal Pradesh Krishi Vishvavidyalaya, Palampur to raise the crop (CSKHPKV, 2010). Five modules including control were $\mathrm{M}_{1}$ : Spray of acephate 75SP@0.7g/L+ Dithane- Z 78 (zineb)@2.5g/L $(0.25 \%)$ after 10 days of appearance of moths in the traps(after 30 days of transplanting) followed by second spray with a mixture of Helicide (Ha NPV) 100 LE@0.5ml/L+ Indofil M-45 (mancozeb) @ 2.5g/L $(0.25 \%)+$ Gur $(0.05 \%)+$ Tween $80(0.05 \%)$ after 15 days of first spray and third spray with a mixture of lamba-cyhalothrin 5EC @ 0.8ml/L(0.04\%) and Ridomil MZ (metalaxyl + mancozeb) $(0.25 \%)$ after 15 days of the second spray; $\mathrm{M}_{2:}$ Spray of spinosad $45 \mathrm{SC}$ (a) $0.2 \mathrm{ml} / \mathrm{L}+$ Score (difenoconazole) @ 1.0g/2L $(0.05 \%)$ after 10 days of appearance of moths in the traps(after 30 days of transplanting) followed by second spray with a mixture of Helicide (Ha NPV) 100 LE@0.5ml/L+ Indofil M-45 (mancozeb) @ 2.5g/L $(0.25 \%)+$ Gur $(0.05 \%)+$ Tween $80(0.05 \%)$ after 15 days of first spray and third spray with a mixture of lamba-cyhalothrin 5EC @ 0.8ml/L (0.04\%) and moximate (cymoxanil+namcozeb) @ 0.25\% after 15 days of the second spray; $\mathrm{M}_{3}$ : Spray with a mixture of lamba -cyhalothrin 5EC@0.8ml/L(0.04\%) and Dithane Z78 (zineb)@2.5g/L (0.25\%) after 10 days of appearance of moths in the traps(after 30 days of transplanting) followed by second spray with a mixture of Helicide (Ha NPV) 100 LE@ 0.5ml/L+ Indofil M-45 (mancozeb) @ 2.5g/L (0.25\%) + Gur (0.05\%) + Tween $80(0.05 \%)$ after 15 days of first spray and third spray with a mixture of lamba-cyhalothrin 5EC @ $0.8 \mathrm{ml} / \mathrm{L}(0.04 \%)$ and moximate (cymoxanil + mancozeb)@ $0.25 \%$ after 15 days of the second spray; $\mathrm{M}_{4:}$ Spray of spinosad 45 SC @ $0.2 \mathrm{ml} / \mathrm{L}+$ Score (difenoconazole)@1.0g/2L (0.05\%) after 10 days of appearance of moths in the traps(after 30 days of transplanting) followed by second spray with a mixture of Helicide (Ha NPV) 100 LE @ 0.5ml/L+ Indofil M-45 (mancozeb) @ 2.5g/L (0.25\%)+Gur (0.05\%)+ Tween $80(0.05 \%)$ after 15 days of first spray and third spray with a mixture of Helicide (Ha NPV) 100 LE @ $0.5 \mathrm{ml} / \mathrm{L}$ and Ridomil (metalaxyl + mancozeb) @ 2.5g/ $\mathrm{L}(0.25 \%)$ after 15 days of the second spray; $\mathrm{M}_{5:}$ Control (Without treatment). Pheromones traps @ 12 traps/ ha just after transplanting the crop for monitoring the population of $H$. armigera were installed in all the modules. Each module received three sprays of pesticides. Sprays of insecticides and fungicides under each module were initiated after about 30 days of transplanting and subsequent sprays were given as per the modules. Fruits were harvested module wise and the data on the damaged and healthy fruits on number and weight basis were recorded at each picking. Total number of infested and healthy fruits and their weight from all the pickings were recorded to work out the per cent borer infestation and fruit rot infection. However, for the marketable yield only healthy fruits at all pickings were recorded. Thus data were recorded on the fruit infestation during the period of experimentation, marketable yield ( $\mathrm{q} / \mathrm{ha}$ ) and loss due to fruit borer and fruit rot diseases under all the five modules.

Due to the fluctuation in the prices throughout the season, the average price of the produce was fixed at Rs.1500/q. Thus economics of different pest management modules was calculated on the basis of market price of tomato@ Rs 1500/q; insecticides/fungicides namely acephate (Acemain 75SP) @ Rs. 660/kg, spinosad (Tracer 45 SC) @ Rs. 18,570/L, HaNPV (Helicide)@ Rs. 2400/L, difencozole (Score 25 EC) @ Rs. 3000/L, zineb (Dithane Z 78) @ Rs. 320/kg, lamba-cyhalothrin (Bravo 5 EC) @ Rs.520/L, Ridomil MZ (Combi product of metalaxyl \& mancozeb) @ Rs.2450/kg, moximate (combi product of cymoxanil \& mancozeb)@ Rs.1330/kg, Tween $80 @$ Rs.1976/L, carbenbazim (Bavistin 50 WP)@ Rs.770/kg and labour charges for pesticide application (Rs. 1200/ha @ Rs. 120/day; total 10 man days/ha. Net additional return (Rs/ha) of each module was calculated by subtracting the total cost (Rs/ha) of pesticide application from net return (Rs/ha) on the pesticide application over the control. Net return per rupee invested was calculated by dividing the net additional return (Rs/ha) with cost of pesticide application. Data on fruit borer infestation, fruit rot incidence, yield loss and marketable yield of the three trials in each year were pooled and analyzed according to the analysis of variance procedure (Rangaswamy, 1995).

\section{RESULTS AND DISCUSSION}

Effect on fruit borer and fruit rot: During both the years of experimentation, all the modules were significantly superior to untreated control in protecting tomato crop from fruit borer and fruit rot diseases. The module $\mathrm{M}_{3}$ was the most effective IPM strategy against fruit borer and fruit rot diseases resulting in minimum fruit borer infestation $(4.86 \%$ and $9.99 \%)$ and minimum fruit rot incidence $(9.01 \%$ and $6.32 \%)$ during 2011 and 2012, respectively. The pooled data of both the years showed fruit infestation by fruit borer to be $7.42 \%$ ( $50 \%$ reduction over untreated control) and fruit rot incidence of $7.66 \%(63.45 \%$ reduction over the untreated control) followed by $\mathrm{M}_{4}$ which recorded $7.73 \%$ fruit borer infestation( $47.91 \%$ reduction over untreated control ) and $8.02 \%$ fruit rot incidence $(61.73 \%$ reduction over untreated control) (Table 1). The present observations regarding the better efficacy of 2 sprays of lamba-cyhalothrin in $\mathrm{M}_{3}$ for the control of fruit borer in tomato are in agreement to those of Sam et al., (2014)who reported lambda super (a.i. lambda-cyhalothrin) and cymethoate super (a. i. cypermethrin and cymothoate) effective against fruit borer in tomato. However, Mishra (2015) reported cyantraniliprole10\% OD @ $105 \mathrm{~g}$ a.i./ha to be effective against fruit borer with lowest fruit damage of $3.0 \%$ on number basis and $3.2 \%$ on weight basis with 86.3 and $85.3 \%$ reduction over control, respectively. Similarly, Ghatak et. al. (2015) reported that combination of mancozeb with cymoxanil and phenamidone rendered 
Table 1. Efficacy of various modules for the management of fruit borer and fruit rot diseases in tomato.

\begin{tabular}{|c|c|c|c|c|c|c|c|c|}
\hline \multirow[t]{2}{*}{ Module } & \multicolumn{4}{|c|}{ Fruit borer infestation (\%) } & \multicolumn{4}{|c|}{ Fruit rot incidence $(\%)$} \\
\hline & 2011 & 2012 & Pooled & ROC* (\%) & 2011 & 2012 & Pooled & ROC* $(\%)$ \\
\hline$\overline{\mathrm{M}_{1}}$ & $\begin{array}{c}5.28 \\
(2.50)\end{array}$ & $\begin{array}{l}10.57 \\
(3.39)\end{array}$ & 7.90 & 46.76 & $\begin{array}{c}10.49 \\
(3.39)\end{array}$ & $\begin{array}{c}6.80 \\
(2.79)\end{array}$ & 8.64 & 58.77 \\
\hline $\mathrm{M}_{2}$ & $\begin{array}{c}5.84 \\
(2.61)\end{array}$ & $\begin{array}{l}10.60 \\
(3.40)\end{array}$ & 8.22 & 44.60 & $\begin{array}{c}9.85 \\
(3.29)\end{array}$ & $\begin{array}{c}8.04 \\
(3.00)\end{array}$ & 8.94 & 57.34 \\
\hline $\mathrm{M}_{3}$ & $\begin{array}{c}4.86 \\
(2.42)\end{array}$ & $\begin{array}{c}9.99 \\
(3.31)\end{array}$ & 7.42 & 50.00 & $\begin{array}{c}9.01 \\
(3.16)\end{array}$ & $\begin{array}{c}6.32 \\
(2.70)\end{array}$ & 7.66 & 63.45 \\
\hline $\mathrm{M}_{4}$ & $\begin{array}{c}5.33 \\
(2.51)\end{array}$ & $\begin{array}{l}10.13 \\
(3.33)\end{array}$ & 7.73 & 47.91 & $\begin{array}{c}8.63 \\
(3.10)\end{array}$ & $\begin{array}{c}7.41 \\
(2.90)\end{array}$ & 8.02 & 61.73 \\
\hline $\mathrm{M}_{5}$ & $\begin{array}{l}11.46 \\
(3.52)\end{array}$ & $\begin{array}{l}18.23 \\
(4.38)\end{array}$ & 14.84 & - & $\begin{array}{l}30.82 \\
(5.64)\end{array}$ & $\begin{array}{c}11.11 \\
(3.47)\end{array}$ & 20.96 & - \\
\hline $\mathrm{CD}(\mathrm{P}=0.05)$ & 0.53 & 0.27 & - & - & 0.18 & 0.21 & - & - \\
\hline
\end{tabular}

* ROC $=$ Reduction over control; Figures in the parentheses are square root $(\sqrt{ } \mathrm{n}+1)$ transformations

Table 2. Marketable yield and yield loss due to fruit borer and fruit rot diseases in tomato.

\begin{tabular}{|c|c|c|c|c|c|c|c|c|c|}
\hline \multirow[t]{3}{*}{ Module } & \multicolumn{6}{|c|}{ Yield loss (\%) } & \multicolumn{3}{|c|}{ Marketable yield (q/ha) } \\
\hline & \multicolumn{3}{|c|}{ Fruit borer } & \multicolumn{3}{|c|}{ Fruit rot diseases } & \multirow[b]{2}{*}{2011} & \multirow[b]{2}{*}{2012} & \multirow[b]{2}{*}{ Pooled } \\
\hline & 2011 & 2012 & Pooled & 2011 & 2012 & Pooled & & & \\
\hline$\overline{\mathrm{M}_{1}}$ & $\begin{array}{c}5.23 \\
(2.49)\end{array}$ & $\begin{array}{c}9.76 \\
(3.13)\end{array}$ & 7.49 & $\begin{array}{l}11.79 \\
(3.57)\end{array}$ & $\begin{array}{c}2.47 \\
(1.85)\end{array}$ & 7.13 & 151.65 & 332.21 & 236.38 \\
\hline $\mathrm{M}_{2}$ & $\begin{array}{c}5.20 \\
(2.48)\end{array}$ & $\begin{array}{c}9.67 \\
(3.22)\end{array}$ & 7.43 & $\begin{array}{c}9.76 \\
(3.28)\end{array}$ & $\begin{array}{c}4.90 \\
(2.41)\end{array}$ & 7.33 & 152.65 & 338.61 & 245.63 \\
\hline $\mathrm{M}_{3}$ & $\begin{array}{c}4.52 \\
(2.34)\end{array}$ & $\begin{array}{c}8.27 \\
(3.03)\end{array}$ & 6.39 & $\begin{array}{c}9.94 \\
(3.31)\end{array}$ & $\begin{array}{c}2.76 \\
(1.93)\end{array}$ & 6.35 & 166.46 & 345.42 & 255.94 \\
\hline $\mathrm{M}_{4}$ & $\begin{array}{c}5.63 \\
(2.57)\end{array}$ & $\begin{array}{c}7.67 \\
(2.92)\end{array}$ & 6.65 & $\begin{array}{c}9.54 \\
(3.24)\end{array}$ & $\begin{array}{c}3.82 \\
(2.15)\end{array}$ & 6.68 & 163.93 & 346.50 & 255.52 \\
\hline $\mathrm{M}_{5}$ & $\begin{array}{l}11.79 \\
(3.57)\end{array}$ & $\begin{array}{l}16.70 \\
(4.18)\end{array}$ & 14.24 & $\begin{array}{l}29.90 \\
(5.56)\end{array}$ & $\begin{array}{c}8.40 \\
(3.06)\end{array}$ & 19.15 & 100.02 & 265.83 & 182.92 \\
\hline $\mathrm{CD}(\mathrm{P}=0.05)$ & 0.62 & 0.47 & - & 0.11 & 0.46 & - & 26.65 & 29.35 & - \\
\hline
\end{tabular}

Figures in parentheses are square root $(\sqrt{ } \mathrm{n}+1)$ transformations.

Table 3. Economics of different modules tested against fruit borer and fruit rot diseases in tomato.

\begin{tabular}{|c|c|c|c|c|c|c|}
\hline \multirow[t]{2}{*}{ Modules } & \multicolumn{3}{|c|}{$\begin{array}{c}\text { Net additional returns } \\
\text { (Rs./ha) }\end{array}$} & \multicolumn{3}{|c|}{ Net returns per Rs. invested } \\
\hline & 2011 & 2012 & Mean & 2011 & 2012 & Mean \\
\hline$\overline{\mathrm{M}_{1}}$ & $65,779.75$ & $87,904.75$ & $76,842.25$ & 5.63 & 7.53 & 6.58 \\
\hline $\mathrm{M}_{2}$ & $66,364.50$ & $96,589.50$ & $81,477.00$ & 5.27 & 7.67 & 6.47 \\
\hline $\mathrm{M}_{3}$ & $90,026.00$ & $1,09,651.75$ & $99,838.62$ & 9.34 & 11.38 & 10.36 \\
\hline $\mathrm{M}_{4}$ & $80,636.25$ & $1,21,776.25$ & $1,01,206.25$ & 5.29 & 7.96 & 6.62 \\
\hline $\mathrm{M}_{5}$ & - & - & - & - & - & - \\
\hline
\end{tabular}

tomato fruit rot incidence between $8-9.3$ per cent. In the present study cymoxanil + mancozeb which was one of the fungicides in module $\mathrm{M}_{3}$, has been found effective in managing fruit rot in tomato. Highest fruit borer infestation $(11.46 \%$ and $18.23 \%)$ and fruit rot incidence $(30.82 \%$ and $11.11 \%)$ was witnessed in the untreated control during 2011 and 2012, respectively with the pooled fruit borer infestation of 14.84 and fruit rot incidence of $20.96 \%$.

Yield loss: The plots with the module $\mathrm{M}_{3}$ (Table 2) registered significantly low yield losses $(\mathrm{P}<0.05)$ due to fruit borer (4.52 and $8.27 \%$ ) and fruit rot diseases (9.94\% and $2.76 \%$ ) during both the years in comparison to untreated control which recorded the yield loss due to fruit borer $(11.79 \%$ and $16.70 \%)$ and fruit rot diseases (29.90\% and 8.40\%) for 2011 and 2012, respectively. Pooled data indicated that yield loss by fruit borer and fruit rot diseases was minimum in $\mathrm{M}_{3}$
(6.39 and $6.35 \%$ respectively). The lowest yield loss in $\mathrm{M}_{3}$ could be attributed for the higher efficacy of the pesticides like lamba-cyhalothrin (which was sprayed 2 times), helicide coupled with spray of fungicides like Indofil M-45, zineb and moximate for controlling the pests with better persistence. Synthetic pyrethroids like lamba-cyhalothrin are also effective at lower concentrations or doses as compared to insecticides of other groups. The present results also find support from the findings of Kumar and Sharma (2004) who recorded minimum yield loss due to fruit borer in lambda -cyhalothrin $(0.004 \%)$ treated plots in tomato crop . However Singh and Singh (2005) and Sudharani and Rath (2011) reported that repeated sprays of endosulfan in tomato crop were efficacious in the control of this pest. But keeping in view the ecological safety, development of resistance in the pest by the use of same chemical and present day concerns on the use of 
endosulfan, some alternate means of control of this pest are warranted. Apart from insecticides, fungicides are also very important in the effective management of fruit rot and foliar diseases of tomato. Ridomil MZ, Dithane M45, Curzate + Indofil M45, Difolatan and copper oxychloride, mancozeb + cymoxanil and mancozeb + phenomedone have been found effective to manage tomato diseases (Verma, et al., 1994; Shyam and Gupta, 1996; Ghatak et al., 2015). However, Shyam and Gupta (1996) also recommended spray schedule using Ridomil MZ 72, mancozeb, captan and copper oxychloride for the economic and effective management of fruit rot caused by Phytophthora nicotianae var. parasitica.

A cursory look on the pooled data of M4 module showed (Table 2) that yield losses by fruit borer and fruit rot diseases was $6.65 \%$ and $6.68 \%$, respectively thus indicating that this was the second best module after M3 with respect to yield losses by fruit borer and fruit rot diseases. This module ( M4) consisting of use of eco-friendly insecticides like spinosad (bacterial fermentation product) and sprays of Helicide ( 2 sprays) having bio-efficacy comparable to most synthetic insecticides, along with fungicides like score, Indofil M-45 and Ridomil MZ could also be taken in to the consideration being effective and environmental friendly. Amin et al. (2013) found different preparation of metalaxyl + mancozeb effective against tomato diseases. These findings are in conformity with 2 nd best treatment (module M4) of the present study in which metalaxyl + mancozeb was used.

Yield and Economics: During the present study marketable yields in all the IPM modules were significantly superior (151.65-166.46 q/ha during 2011 and 332.21-346.50 q/ha during 2012) $(\mathrm{P}<0.05)$ to the control (100.02 q/ha during 2011 and $265.83 \mathrm{q} /$ ha during 2012). The difference in the marketable yields of two years may be inter alia due to variation in the climate of the two years and soil type of the fields where the trials were conducted. Among the modules, highest pooled yield was obtained $(255.94 \mathrm{q} / \mathrm{ha})$ from M3. However this was followed by module M4 which recorded the pooled yield of $255.52 \mathrm{q} / \mathrm{ha}$.

Net returns/rupee invested were Rs. 5.63, and Rs.7.53 for $\mathrm{M}_{1}$, Rs. 5.27 and Rs.7.67 for $\mathrm{M}_{2}$, Rs. 9.34 and Rs.11.38 for $\mathrm{M}_{3}$ and Rs. 5.29 and Rs. 7.96 for $\mathrm{M}_{4}$ for the years 2011 and 2012, respectively (Table 3). The highest net returns/rupee invested for $\mathrm{M}_{3}$ (Rs. 9.34 and Rs.11.38) in comparison to $\mathrm{M}_{2}$ and $\mathrm{M}_{4}$ could due to the fact that besides other pesticides spinosad was used in these two modules, which had quite higher market price (Rs. 18,570/L) than other pesticides resulting in less net returns. The present results are more or less in conformity to those of Kumar et al. (2010) who tested eight 3 -spray schedules for the integrated management of fruit borer, foliar and fruit rot diseases of tomato and concluded that a spray schedule consisting of sprays with a mixture of contaf $(0.05 \%)$ and endosulfan $(0.05 \%)$ at flower initiation stage (35 days after transplanting) followed by a second spray of a mixture of copper oxichloride $(0.3 \%)$ and lambda-cyhalothrin $(0.04 \%)$ after 15 days and third spray with Indofil M$45(0.25 \%)$ after 15 days of second spray was the most effective and economical giving the average net additional returns of Rs.1,19,675/ha with cost : benefit ratio of $1: 3.77$.

\section{Conclusion}

Thus it could be concluded that module $\mathrm{M}_{3}$, consisting of use of pheromone traps followed by three foliar sprays commencing with a mixture of lambacyhalothrin and Dithane Z-78 (Zineb) after 30 days of transplanting followed by the second spray with a mixture of Helicide (Ha NPV) + Gur + Tween 80 after 15 days of first spray followed by the third spray with a mixture of lamba-cyhalothrin 5EC and moximate (cymoxanil + mancozeb) after 15 days of the second spray, being the most effective and economic, could be used for the management of fruit borer and fruit rot diseases in tomato (Lycopersicon esculentum). Besides, this will also result in the tremendous reduction in number of sprays in tomato crop along with the reduction in the cost of production and relief from the the heavy inconvenience caused to the farmers by saving of their precious time, labour, money and resources.

\section{REFERENCES}

Abbas, G., Hassan, N., Farhan, M., Haq, I. and Karar, H. (2015). Effect of selected insecticides on Helicoverpa armigera Hubner (Lepidoptera:Noctuidae) on tomato (Lycopersicon esculentum Miller)and their successful management. Advances in Entomology, 3:16-23.

Amin, N., Mulugeta, N. and Selvaraj, T. (2013). Field evaluation of new fungicide Victory $72 \mathrm{WP}$ for the management of potato and tomato late blight ( Phytophthora infestans (Mont) debary) in West Sewa Highland, Oromia, Ehiopia. Journal of Plant Pathology and Microbiology, 4(8): 192 http://d.doi.org/ 10.4172/21577471.1000192.

Chaurasia, A. K., Chaurasia, S., Chaurasia, S., and Chaurasia, S. (2013). Studies on the development of fruit rot of tomato caused by Alternaria solani ( Ellis \& Mart) Jones and Ground. International Journal of Pharmacology and Life Sciences, 4(6):2713-2716.

CSKHPKV (2010). Package of Practices for vegetable crops, pp7-23. Chaudhary Sarwan Kumar Himachal Pradesh Krishi Vishvavidyalaya, Palampur.

Ghatak, A., Ansar, M., Ghatak, L.V. and Balodi, R. (2015). Elucidation of relationship between phytophthora leaf blight and fruit rot in tomato. Journal of Post Harvest Technology, 3(2):50-57.

Kumar, J. and Sharma, S.D. (2004). Efficacy and economics of Bacillus thuringiensis var kurstaki for the management of Helicoverpa armigera on tomato (Lycopersicon esculentum) in lower Kullu valley, Himachal Pradesh. Indian Journal of Agricultural Sciences, 74 (7): 396398.

Kumar, J., Devlash, R. and Sharma, S.D. (2010). Integrated management of fruit borer, foliar and fruit rot diseases 
of tomato in Kullu valley of Himachal Pradesh. In: Verma, A.K., Gupta, P.R.,Bhardwaj, S.P. (eds.) Abstracts National Symposium on Perspectives and challenges of integrated pest management for sustainable agriculture, Nov. 19-21, 2010. Abstract No.6.13 pp.196.

Misra, H. P. (2015). Cyantraniliprole (Cyazypyr) - a new Anthranilicdiamide insecticide against tomato fruit borer, Helicoverpa armigera. Indian Journal of Plant Protection, 43(1): 1-5.

Rangaswamy, R. (1995). A Text Book of Agricultural Statistics. New Age International Publishers Ltd., New Delhi. 89-101.

Reddy, G. V. P. and and Tangtrakulwanish, K. (2013). Action threshold regimens for red spider mite and fruit borer on tomato. Florida Entomologist, 96:1084-1096.

Sam, G. A., Osekrel, E. A., Mochiah, M. B. and Kwoseh, C. (2014). Evaluation of insecticides for the management of insect pests of tomato. Journal of Biology, Agriculture and Healthcare, 4(5), 2014. ISSN 2224-3208 (Paper) ISSN 2225-093X (On line)
Shyam, K. R. and Gupta, S. K. (1996). Fungicidal control of buck eye rot (Phytophthora nicotianae var. parasitica) and Alternaria leaf spots (Alternaria alternata, A. alternata fsp. lycopersici) of tomato ( Lycopersicon escuentum). Indian Journal of Agricultural Sciences, 66(5): 309-312.

Singh, P.S. and Singh, A.N. (2005). Efficacy of certain management modules against Helicoverpa armigera on tomato. Shaspa, 12: 111-113.

Sudharani, D and Rath L. K. (2011). Biopesticides against fruit borer complex in tomato. Indian Journal of Plant Protection, , 39(4) : 316-317.

Verma, T. S., Chand, Ramesh, Lakhanpal, K. D., Sharma, S.C. and Chand, R. (1994). Use of fungicides in controlling fruit rot and increasing fruit and seed yield in tomato. Himachal Journal of Agricultural Research, 20:44-48.

Wani, A.H. (2011). An overview of the fungal rot of tomato. Mycopathology, 9 (1):33-38 